\title{
A Citizen Science Approach to Build a Knowledge Base and Cadastre on Earth Buildings in the Weinviertel Region, Austria
}

\author{
Thomas Schauppenlehner $^{1, *(\mathbb{D})}$, Renate Eder ${ }^{1} \mathbb{D}, \operatorname{Kim}_{\text {Ressar }}{ }^{1} \mathbb{D}$, Hubert Feiglstorfer $^{2,3} \mathbf{D}^{\mathbb{D}}$, Roland Meingast $^{3}$ \\ and Franz Ottner ${ }^{3}$
}

1 Institute of Landscape Development, Recreation and Conservation Planning (BOKU, ILEN), University of Natural Resources and Life Sciences, 1180 Vienna, Austria; renate.eder@boku.ac.at (R.E.); kim.ressar@boku.ac.at (K.R.)

2 Institute for Social Anthropology, Austrian Academy of Sciences (ÖAW, ISA), 1020 Vienna, Austria; hubert.feiglstorfer@oeaw.ac.at

3 Institute for Applied Geology (BOKU, IAG), University of Natural Resources and Life Sciences, 1190 Vienna, Austria; roland.meingast@lopas.at (R.M.); franz.ottner@boku.ac.at (F.O.)

* Correspondence: thomas.schauppenlehner@boku.ac.at

check for updates

Citation: Schauppenlehner, T.; Eder, R.; Ressar, K.; Feiglstorfer, H.; Meingast, R.; Ottner, F. A Citizen Science Approach to Build a Knowledge Base and Cadastre on Earth Buildings in the Weinviertel Region, Austria. Heritage 2021, 4 , 125-139. https://doi.org/10.3390/ heritage 4010007

Received: 17 December 2020 Accepted: 8 January 2021 Published: 13 January 2021

Publisher's Note: MDPI stays neutral with regard to jurisdictional clai$\mathrm{ms}$ in published maps and institutional affiliations.

Copyright: (C) 2021 by the authors. Licensee MDPI, Basel, Switzerland. This article is an open access article distributed under the terms and conditions of the Creative Commons Attribution (CC BY) license (https:// creativecommons.org/licenses/by/ $4.0 /)$.

\begin{abstract}
Clay played a decisive role as a building material in the Austrian Weinviertel region Its traditional use in vernacular architecture started to disappear in the 19th century, triggered, for example, by upcoming industrial processes to produce construction materials such as burnt bricks, and by making them available as mass building products in course of the time-even for vernacular purpose and at remote places. Following a debate on ecological sustainability during the last decades, the striking advantages of clay as a building material have been rediscovered. However, to support restoration activities and develop new uses, a vital and profound knowledge of properties of the local clay and its traditional local use is required. It is therefore important to increase the knowledge of this unique heritage among the local population and the scientific community. This article aims to present the development of an earth building cadastre (Lehmbaukataster) based on an innovative Citizen Science approach using mobile technologies for activating and integrating the local population with specific local and historical knowledge of earth architecture in the Weinviertel. The results show that citizens can provide essential information to develop a cadastre on earth buildings. Supported by a web application with GPS location facilities, camera, and low entry barriers, citizens can contribute to the expansion of the scientific database. The research results are a strong impetus for the development of strategies for the valorization and protection of cultural heritage.
\end{abstract}

Dataset License: All data from the Citizen Science platform Lehmbau im Weinviertel can be used freely and free of charge for both private and commercial purposes in accordance with the Creative Commons-Attribution license (CC-BY 4.0). Credit must be given as follows: Data source: ( Lehmbau im Weinviertel-Contributors-CC-BY 4.0 via cs-lehmbau.boku.ac.at whereby "cs-lehmbau.boku.ac.at" must be used as a link to http:/ /cs-lehmbau.boku.ac.at in digital media and publications.

Keywords: Citizen Science; knowledge transfer; web and mobile applications; earthen architectural heritage; cultural heritage; clay; building traditions; vernacular architecture

\section{Introduction}

For centuries, clay was a dominating building material in rural areas of Central Europe [1], particularly in the Austrian Weinviertel region [2]. A variety of earth building techniques influenced the development of unique vernacular architectural building traditions [3,4], which influenced the landscape scenery and the development of cultural identities [5-9]. A transnational discourse shows particularities and technical interrelations among local earth building techniques [10-13]. Nowadays, many of the vernacular earth buildings are abandoned, but clay as an ecological building material is of growing 
interest $[2,14]$. Restoration activities and recent applications are demanding detailed information about historical processing techniques and applications [15]. As past rural life is poorly documented in historical documents [16], existing architectural fragments are important to enhance the scientific understanding about earth architecture. The integration of local inhabitants using a Citizen Science approach [17] and new technologies such as web mapping and mobile devices offers promising opportunities for scientific projects about earth buildings. The availability of affordable innovative technologies and web-based services lowers the entry barriers for participation and provides appropriate techniques for knowledge transfer [18]. This article presents the development of an earth building cadastre (Lehmbaukataster) using a Citizen Science framework to expand the knowledge base about earth buildings in the Austrian region of Weinviertel using mobile web technologies and a comprehensive set of training and information media. The aim is to answer the question to what extent Citizen Science can contribute to a broader understanding of local and historical earth building techniques and what a corresponding approach to this might look like. The "Research materials and methods" section provides a brief overview of the study region and the role of earth buildings, followed by a description of the developed Citizen Science framework. The "Results" section gives an overview about the outcomes of our study, divided into the different Citizen Science modules followed by examples from the earth building cadastre with an interpretation and classification in terms of regional and national earth building history. The "Conclusions" chapter synthesizes and summarizes the approach, and in the "Discussion" chapter we present considerations beyond the project about future research approaches and demands.

\section{Research Material and Methods}

\subsection{Study Region}

The research project Lehmbau im Weinviertel was carried out in the Weinviertel region, the most northeastern part of Austria, bordering the Czech Republic (Moravia region) in the north and Slovakia in the east (see Figure 1).

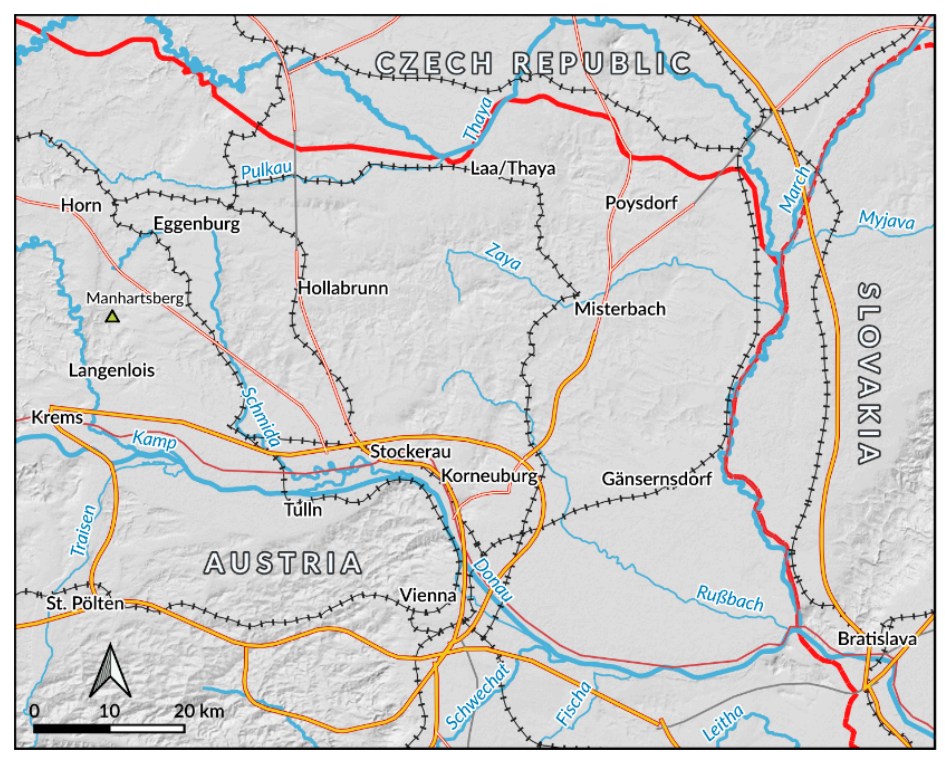

(a)

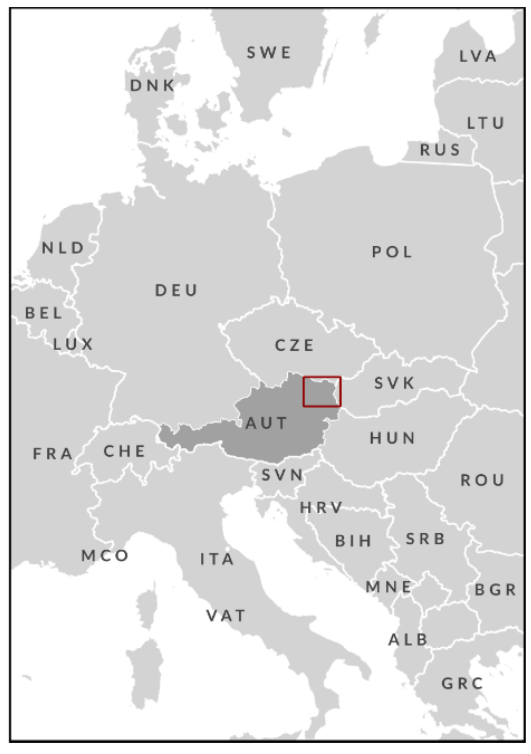

(b)

Figure 1. (a) Weinviertel study region in the northeast of Austria and (b) the region located in Europe (Data Sources: Natural Earth Data, 2020; Copernicus Land Monitoring, 2020).

Framed by the rivers Thaya (north), Danube (south), and March (East) the Weinviertel is a rural region, dominated by agricultural production such as crop cultivation and viticulture. The relief energy is fairly low, and sea level ranges from $130 \mathrm{~m}$ (in the southeastern 
parts) up to $500 \mathrm{~m}$ (in the northwestern parts). The region pertains to the Pannonian climate zone with hot summers, cold winters, and precipitation between $500 \mathrm{~mm}$ and $600 \mathrm{~mm}$ per year. As forestation is limited, timber played only a minor role in traditional construction techniques - this is one reason for the historical use of mineral building materials, in particular clay. The geology of the Weinviertel is dominated by three large and two smaller tectonic units. The Vienna Basin is in the eastern part of the Weinviertel, separated by the Waschberg unit from the Molasse unit in the west. The Manhartsberg is the westernmost unit. This unit belongs to the Bohemian Massif. A small strip parallel to the Waschberg unit is part of the Flysch unit. During the Ice Age, high amounts of loess were transported by wind and sedimented in that area [19-22]. Today, this young sediment is widespread in the whole Weinviertel.

\subsection{The Cultural Heritage of Earth Buildings in the Weinviertel Region}

Building with clay played an important role in the Weinviertel region, as the material was freely available, and techniques such as cob (local term gesatzter Lehm or Gsatzt), or earth lumps (local term Wuzel or Lehmwuzel) [23] were applicable without any costly technical equipment [24-27]. Due to manorial and later governmental prescriptions, brick burning was not allowed for common people like farmers until 1848. Although the ban was formally lifted in 1773, until 1848, it was de facto impossible for the dependent peasants to operate brick kilns due to the considerable bureaucratic obstacles. Therefore, agricultural buildings such as farmhouses, barns, stables, or earth cellars were built with clay; however, we also find clay as a building material for bourgeois buildings and townhouses. From the mid-19th century, clay was increasingly replaced by industrially prefabricated materials such as burned bricks, steel, or concrete.

Several developments impact the cumulative abandonment and disappearance of earth architecture in the Weinviertel region. Shifts in the agricultural practice led to an abandonment of traditional infrastructures such as earth cellars or barns. Wooden wine presses, in particular the so-called Baumpresse and wooden barrels for wine storage were replaced by tanks made of stainless steel. Modern control technology also stimulated a change in the location of production and storage. In the past, press houses and wine cellars-in this region situated in the so-called Hintaus, represented a transition border from the settled to the agricultural land. Today, its utilization as a processing area for agricultural goods is mostly replaced by larger factory-like halls and agricultural facilities, contrary to the Hintaus in close vicinity to the farmhouse.

This shift from the Hintaus to a more central infrastructure left many of the earth cellars and press houses neglected for agricultural use and many of these buildings became secondary residences or leisure spaces of city dwellers. Demographic changes such as rural depopulation and secondary home trends cause abandoned village centers and the development of new family home settlements on the outskirts. While in some areas a tendency towards resettlement is obvious, today, the keepers of local traditions are mainly those whose ancestors had settled in a vernacular ambience and became part of a traditionally grown village community. Both groups of residents-those who settled recently and those who live there for generations-have their particular needs regarding architectural heritage and conservation of historical structures, and basic questions about the method of conservation arise. At this point, expert advice is needed, which covers the traditional understanding of earthen architectural heritage and its cultural values, as well as professional support of the owners in technical and economic building matters.

\subsection{Research Goals}

Given the fact that over the last decades clay has been gaining attention as a regional and sustainable building material of high ecological value, Citizen Science can be an efficient approach to minimize knowledge gaps about historical earth construction techniques and to learn from the local architectural heritage for sustainable future use. Therefore, we postulated two major goals for our study: 
1. integration of specific knowledge from local residents to increase scientific knowledge about earth architecture in the Weinviertel region and

2. knowledge transfer about earthen architectural heritage from the scientific community to the local population.

We address these two objectives by developing a Citizen Science framework as a foundation for an earth building cadastre (Lehmbaukataster).

\subsection{Citizen Science Framework}

Citizen Science [17] is hardly new, as this approach goes back at least to the National Audubon Society's annual Christmas bird count, which began in 1900 [28,29]. Today, Citizen Science is a rapidly growing field that enables citizens to take part in scientific processes $[29,30]$, often supported and guided by digital and mobile technologies. Citizen Science is not necessarily dependent on the intensive use of technologies such as web services, apps and mobile devices, but they are a means to an end for supporting collaborative working and data gathering. Latest smartphones and tablets are equipped with global positioning systems (GPS), compass, gyroscope, and a camera, and therefore allow the recording of detailed location-based environmental data. The participants enter their data using simple survey forms and internet access allows an immediate transfer to the project database as well as the integration of data from other contributors. Successful apps need a target-group oriented design and usability [31] but also a clear framework regarding ethical and legal aspects of data collection that needs to be communicated transparently.

To provide a methodological basis for our study, we developed a Citizen Science framework (see Figure 2), including comprehensive media for citizen training and knowledge transfer. Besides, an accompanying legal framework has been developed to address the legal and privacy aspects of the building owners and the contributing citizen scientists.

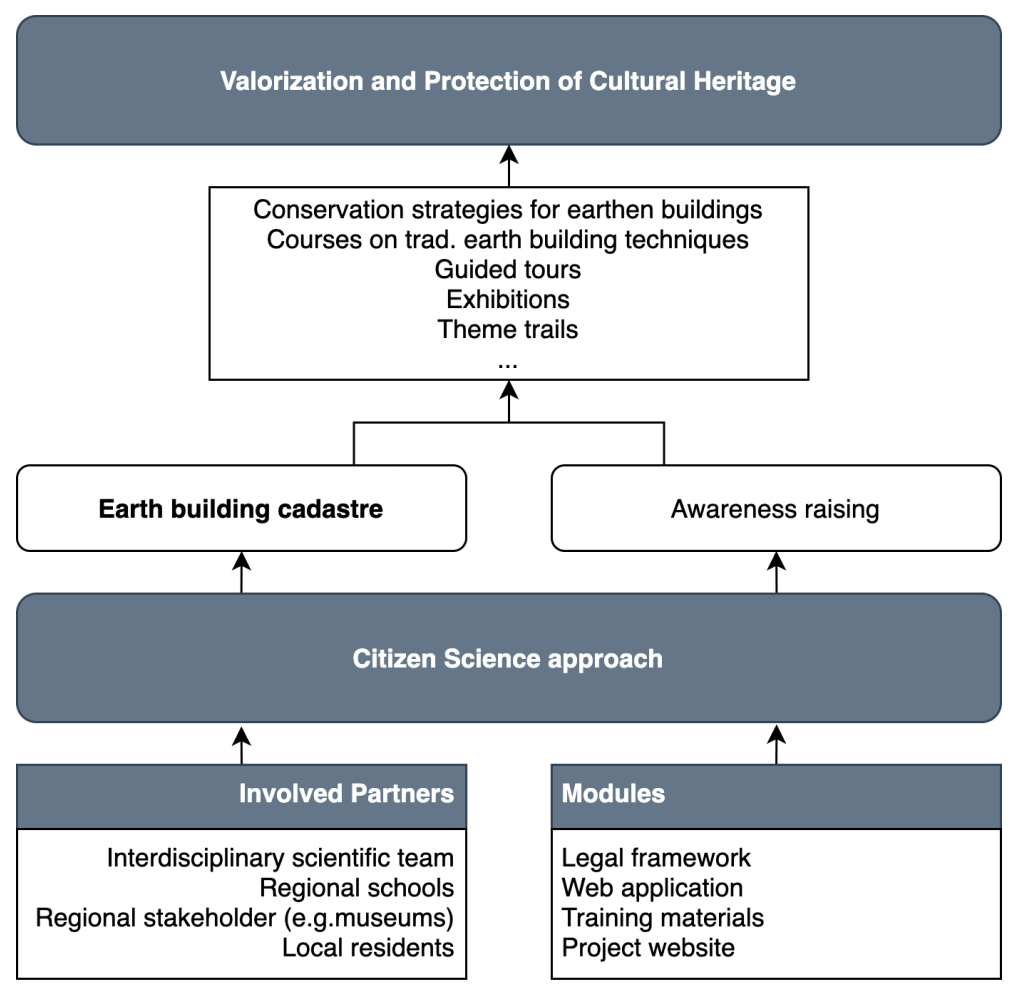

Figure 2. Citizen Science framework for the valorization and protection of cultural heritage.

Many Citizen Science projects are based on proprietary software or have no transparent data sharing policy. As data sharing is a key component of ethical research [32], an additional research goal was to develop a guideline for transparent data sharing mainly based 
on the Creative Commons license framework (creativecommons.org). This means that others can capitalize on the work to promote dialogue, debates, or critical feedback [33].

Citizen Science projects require a clear concept for knowledge transfer in both directions (scientists to citizens, and vice versa) as well as proper training and information materials for citizens to support the collection of reliable data [28]. Nowadays, materials for training and education as well as data collection can be easily supplied by using web technologies but specific target group demands need to be considered [31]. To determine the strengths and weaknesses of Citizen Science projects, a systematic collection of evaluation information is necessary to improve overall effectiveness as well as data quality [34].

Figure 2 shows the scheme of our Citizen Science approach with a foundation consisting of different partners and regional multipliers as well as modules for the legal, technical as well as pedagogical aspects to create an earth building cadastre as a web application and a database to initiate awareness-raising for the cultural heritage of earth buildings in the Weinviertel.

Methodologically this process was carried out as an iterative process between software and media development and evaluation cycles with experts (lawyers, architects, and geologists) and laypersons. For the latter group, we worked with a regional secondary school to test both the media and the platform itself. Results of these workshops were processed to refine the Citizen Science application and supporting digital media. The Citizen Science process itself was evaluated through reflective feedback workshops with the participating pupils. These workshops focused on the usability and clarity of the supporting materials, but also on personal impressions and possible changes in their view of cultural heritage in their familiar environment.

\section{Results}

The involvement of citizen scientists started in spring 2018 with a kick-off event in the Weinviertel region supported by the Museumsdorf Niedersulz. This regional museum exhibits and documents the rural life in the Weinviertel covering the end of the 19th and the beginning 20th century. Additionally, articles promoting the Citizen Science project were launched in regional news media. The platform is still accessible for new contributions, student work, and as an information hub on the topic of earthen building architecture in the Weinviertel region for a broader public. The following sections describe the components and results of the developed Citizen Science framework for building a knowledge base for earth buildings in the Weinviertel.

\subsection{Legal Framework for the Citizen Science Approach}

Citizen Science projects require a comprehensive framework on legal aspects to protect scientists, citizen scientists, and third parties (e.g., building owners) [35]. Scientists need a legal framework that regulates the use of data and takes ethical aspects into account. This is why we have opted for an Open Culture License to ensure the broadest possible and free use of data while complying with the rules of citation (Creative Commons Attribution 4.0 International; https: / / creativecommons.org/licenses/by/4.0/).

Taking into account the data protection aspects of the citizen scientists, the amount of personal data stored has been reduced to the necessary minimum. According to the General Data Protection Regulation (GDPR), all contributors have the right to access their personal data and can request data deletion by email. Apart from a valid email address to prevent misuse and to exclude bots, no further personal data are required for registration.

Third parties can be affected if citizen scientists infringe personal and/or property rights of the object owners. Therefore, a comprehensive and easy-to-understand guide was developed that helps users to determine their options and possibilities in the field. The legal framework is published on the project website http:/ / cs-lehmbau.boku.ac.at/datenschutz/. 


\subsection{Web Application for Data Gathering, Analysis, and Knowledge Transfer}

For data collection, we use a web application based on PHP [36], mySQL [37], and the Leaflet JavaScript framework for interactive maps (https: / /leafletjs.com). Citizen scientists can contribute data by marking the location of an earth building object on an interactive map (see Figure 3) and filling out a simple survey form. Furthermore, images can be added to illustrate the captured building.

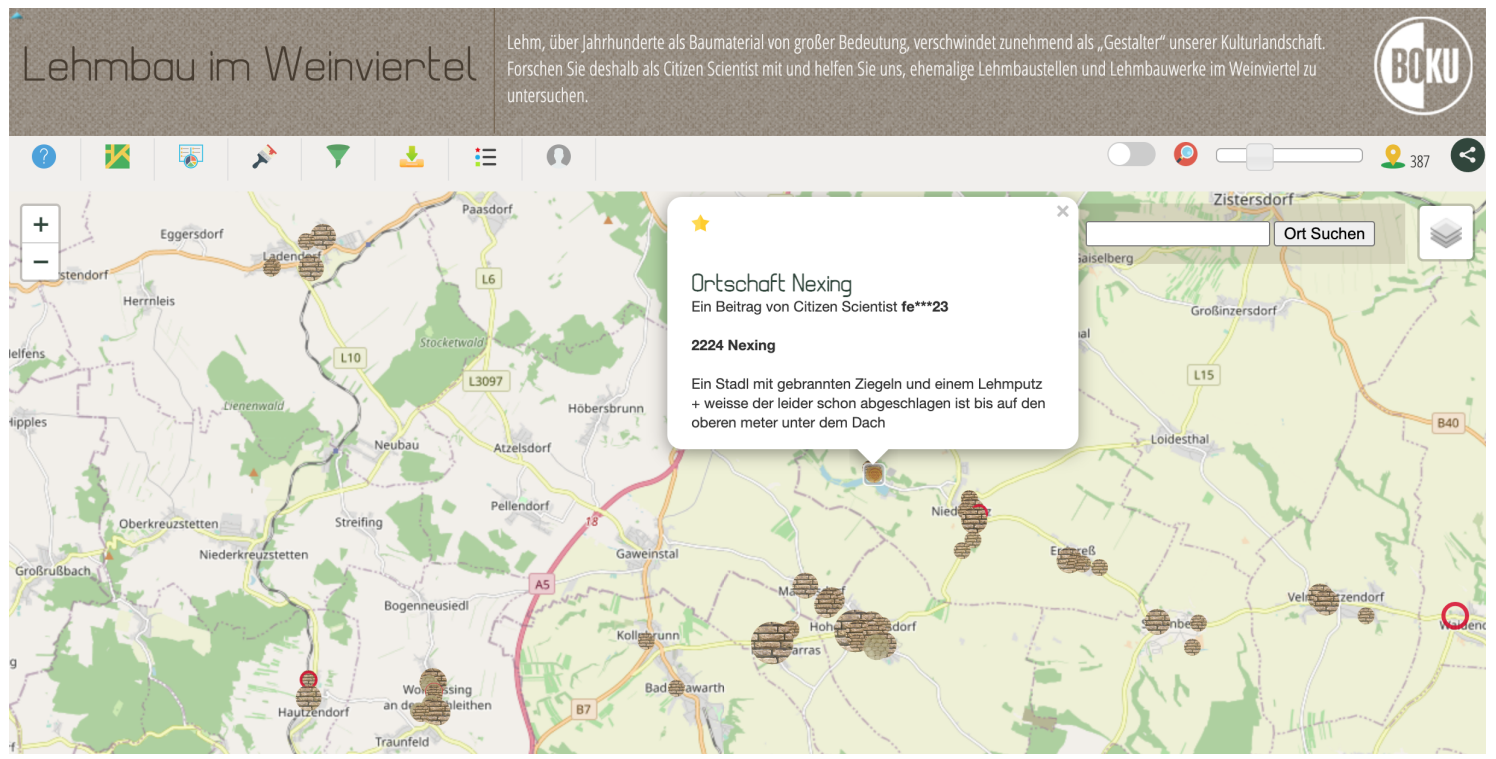

Figure 3. Web interface of the main screen with datasets from citizen scientists and one marked entry with further information.

Through the implementation of a responsive design approach, the user interface is adapted automatically for different screen sizes and resolutions. As a result, many restrictions regarding different smartphone models and screen resolutions can be reduced to a minimum. This also allows seamless on-site use of the application with smartphones and tablets (see Figure 4). Current geolocations can be received, and images of the surveyed object can be taken and uploaded. The basis for this application was developed within the project Think Spatial! (http:/ / thinkspatial.boku.ac.at), a research project investigating new methods for spatial learning with mobile devices [38].
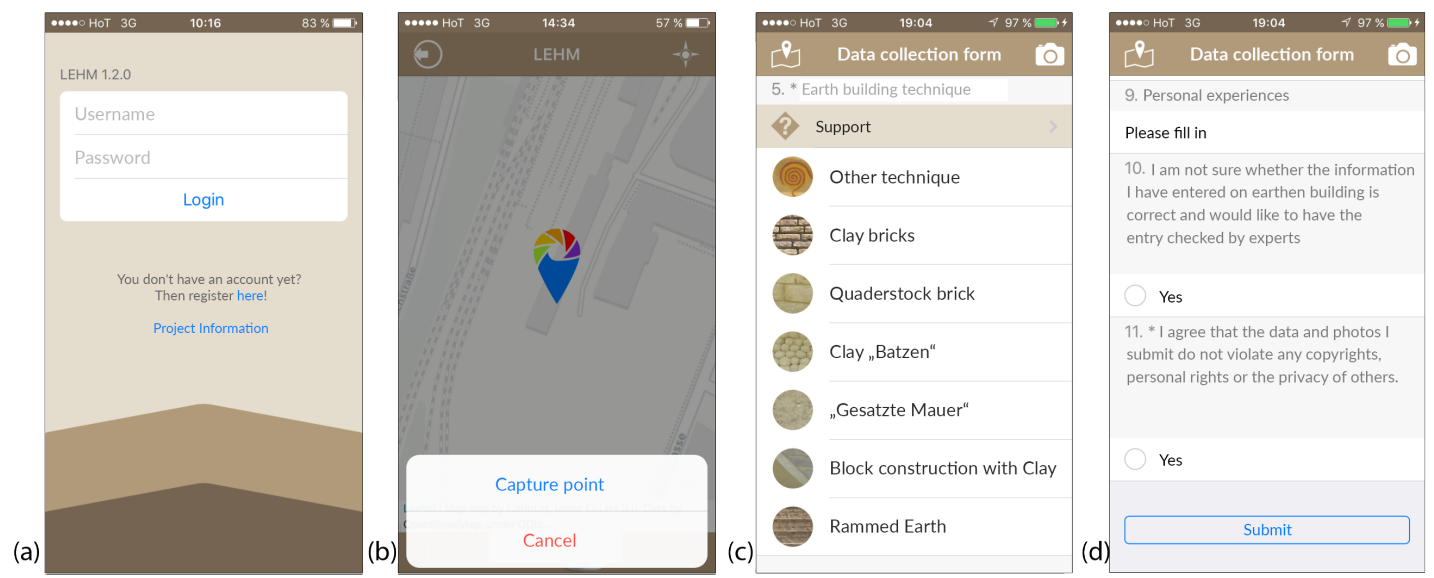

Figure 4. Interface screens on smartphones: Login screen (a), map for locating earth buildings (b), and parts of the survey form $(\mathbf{c}, \mathbf{d})$. Note: The text content of this image was translated from German to English. 


\subsection{Supportive Material for Citizen Training and Guidance}

Proper supportive materials represent a key aspect to derive valid and usable data entries. Therefore, we developed different media and tools for target-group-specific information and training. We identified different major groups of users:

1. Academic students

2. Pupils from regional secondary schools

3. Associations and local initiatives

4. Local inhabitants with a local knowledge and interest in earth architecture

The main goal was to teach the participants to enable them to identify earth buildings and earth building techniques. Therefore, a handbook in PDF format (see Figure 5) describes clay as building and construction material in a comprehensive way and at different levels. Users can choose how deep they want to immerse into the thematic field-from a summarizing overview, to find the most important construction techniques used in the Weinviertel region down to more detailed descriptions and characteristics of clay utilization and techniques. The manual concludes with a determination test (decision tree) of earth building techniques as a supportive tool for field investigations.

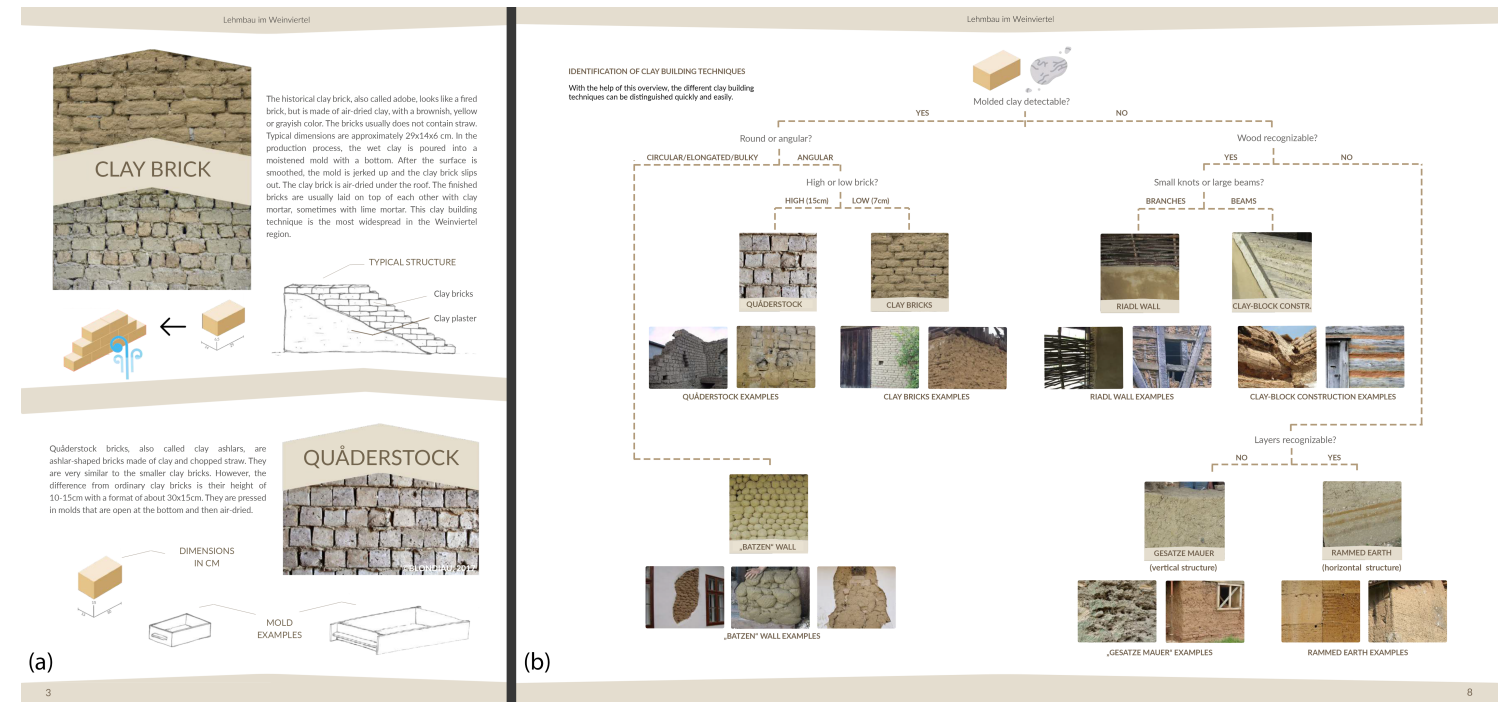

Figure 5. Two sample pages from the handbook on construction techniques: (a) detailed description of building techniques and (b) a decision tree for field investigations. Note: The text content of this image was translated from German to English.

Due to the very different building conditions (from newly renovated to abandoned or dilapidated) the identification of specific building techniques can be quite challenging. To address this problem, citizen scientists can indicate that they are uncertain in their assessment when entering a data set. The record is then marked accordingly and can be assessed and approved or corrected by experts.

Furthermore, a technical guide for the application supports the citizen scientists in getting the data gathering tools up and running. In general, the application is self-explaining, but with this guidance people with less computer experience were also supported.

To address and involve also a younger audience, a more playful approach to motivate people for participation was realized by developing an online quiz on earth buildings. The quiz deals with the historic and geographic aspects of earth buildings, contemporary and historic earth architecture on a global scale and earth building techniques in Central Europe.

To inform multipliers and stakeholders (e.g., teachers, museums, local associations, etc.), a comprehensive online presentation provides an overview about the ecological importance of clay, common traditional building techniques and how to take part in the project. Finally, workshops have been provided that addresses schools, associations as well as future crafts(wo)men working with clay. 
All media are released under the Creative Commons Attribution license (CC-BY 4.0) and can be downloaded from the project website (http:/ / cs-lehmbau.boku.ac.at). A free supply of the materials supports the dissemination of earth building knowledge and encourages multipliers to integrate the project into their activities (e.g., school lessons, exhibitions, academic teaching, master and bachelor thesis, etc.).

\subsection{Collected Earth Building Data}

By the end of 2020, there are already 380 entries in the earth building cadastre (Lehmbaukataster), with a scope and depth of the entries depending on the knowledge of the contributing users. Besides a strong interest by citizens, the Lehmbaukataster is used as a teaching tool in the fields of architectural history, natural and technical science, and building practice at the University of Natural Resources and Life Sciences, Vienna (BOKU Vienna) and at the Vienna Technical University (TU Vienna), see, for example, in [39-42]. Members of the working group Lehmbau (ARGE Lehmbau), a cooperation of researchers, university teachers, and practitioners, were significantly involved in the development of the earth building cadastre. The easy-to-use data entry mask focuses on essential aspects of earth buildings, which are recorded qualitatively and quantitatively. The categorization according to different earth building techniques, construction methods, and sizes of earth buildings enables a regional analysis of vernacular buildings. The range of selectable parameters includes essential building typologies of vernacular architecture in the Weinviertel. The following examples show some aspects of the great diversity of earth building techniques that we can find in the earth building cadastre of the Weinviertel. An example in a cellar lane at the south-western end of the village of Asparn shows adobe bricks and an alternating application of burnt and adobe bricks (so-called Sparbauweise) as the predominant earth building techniques here. The text entry in the Lehmbaukataster shows that there are 38 buildings in this cellar lane, about $80 \%$ of which have been preserved, most of which are buildings made of burnt bricks.

The desolate buildings were predominantly those made of adobe bricks using the Sparbauweise (see Figure 6a). One construction method of gable walls is the erection of the walls with adobe bricks and the gables on top of them with burnt bricks (see Figure 6b). We also find the use of door and window lintels in various designs in the Weinviertel. One variant, for example, is the use of wooden lintels (see Figure 6c).
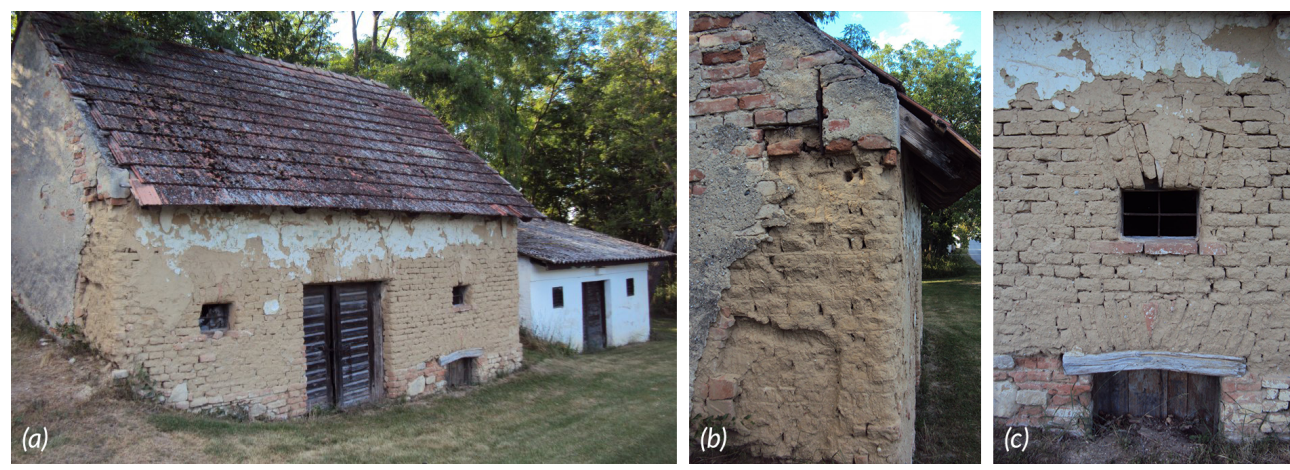

Figure 6. Building example from a cellar lane in Asparn: (a) building wall as a mixture of burnt and adobe bricks, (b) gable wall construction, and (c) flat wooden lintel above a window opening. (Image Source: (C) Lehmbau im WeinviertelContributors-CC-BY 4.0).

In the example above, the window opening is built over the entire depth of the wall with wooden elements as a support of the substructure for the rather flat lintel arch made of adobe bricks. A plinth made of burnt bricks serves as a support for the wooden lintel. The situation is different with the window above, which is only about half the width of the one below (see Figure 6c). The bricks in the upper area of this window's parapet consist of burnt bricks. Because of the smaller span, the lintel was built as a lintel arch built with adobe bricks without an underlying wooden lintel as support. 
Entries from the village of Watzelsdorf show buildings constructed with so-called Quåderstock. They are made similarly to adobe bricks in wooden models, but are much larger than adobe bricks and mixed with pieces of straw and organic waste from threshing. They can often be found in walls of barns or press houses, but also in walls of residential parts of rural buildings (see Figure 7a). In many cases, more detailed information about the traditional building technique of the respective object can only be obtained in the course of building research during renovation or refurbishment measures-in the worst case, however, only when a building is demolished (see Figure $7 \mathrm{~b}$ ). The complete dismantling of an object provides an insight into the building and construction techniques as well as the processing of the individual components.
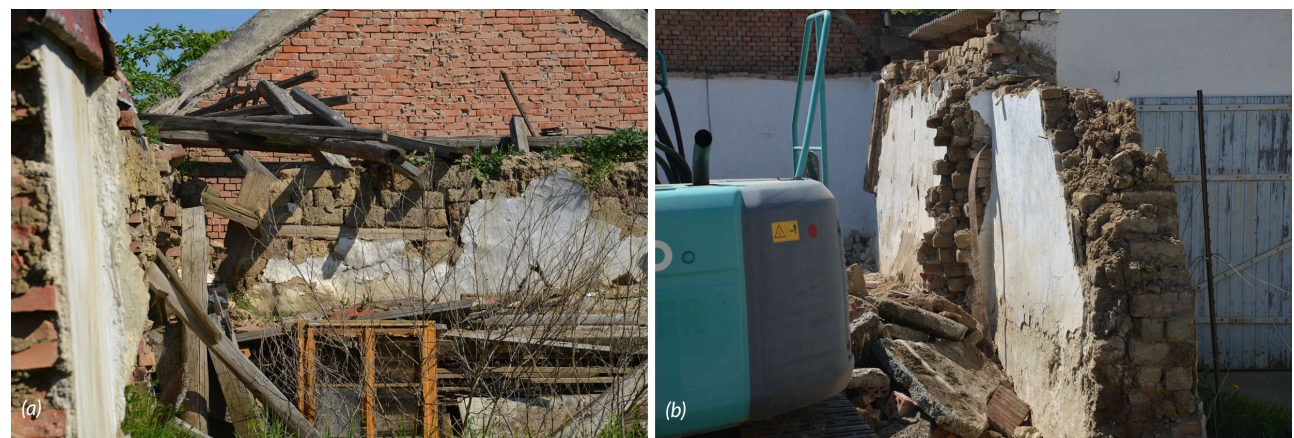

Figure 7. Building ruin in Watzelsdorf: (a) Part of the Quåderstock wall, (b) insights into the cross section during dismantling of the building (Image Source: (C) Lehmbau im Weinviertel-Contributors-CC-BY 4.0).

Although the project focus is on the Weinviertel, contributions from other regions are increasingly being uploaded to the platform. Entries such as the one in Nea Koroni in the Peloponnese in Greece show that related construction techniques can also be found in regions outside the Weinviertel (see Figure 8a). The following text entry can be found (quote translated from German).

The clay building is in an olive grove near Nea Koroni in Messines (Greece). The building is currently unused and seems to be in disrepair. Some renovation work has been carried out in the past, for example, the roof has been completely renewed and plastered with cement. Remnants of the old roof can be seen. Some sections of the wall were also plastered with cement. The bottom $30 \mathrm{~cm}$ of the building are made of stone that has been plastered with clay, some renovations with cement can also be seen here. The large components in the clay are noticeable. These consist of fossilized shells and stones. The color is yellow.

The earth building technique applied here is also based on Quåderstock similar to the technique in the Weinviertel, which at the Greek example are placed on a stone plinth (see Figure 8b).
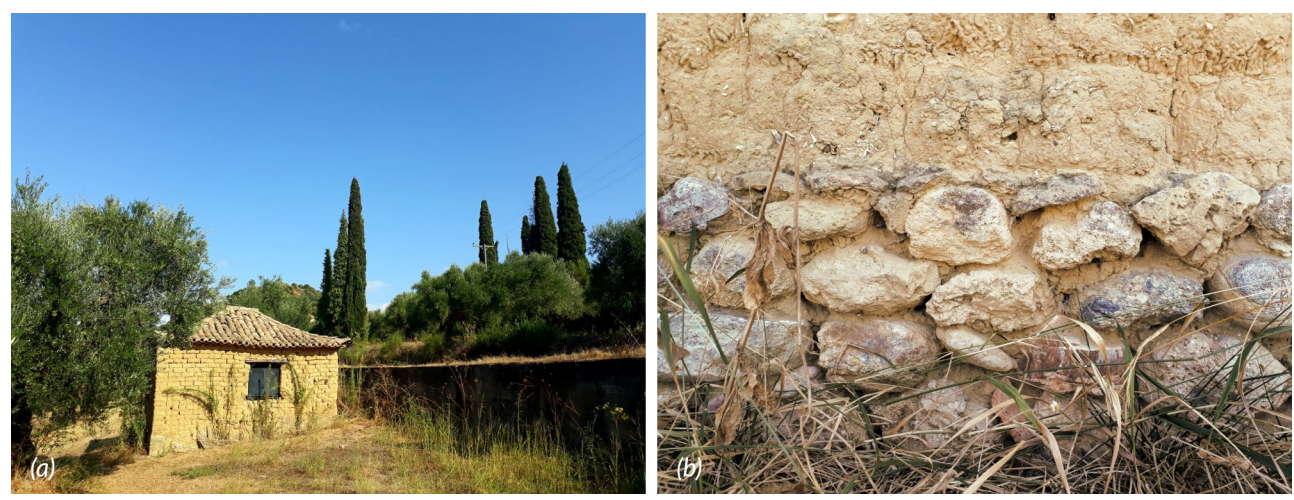

Figure 8. (a) Building example from Nea Koroni in Messines (Greece). (b) Stone foundation with Quåderstock (Image Source: (c) Lehmbau im Weinviertel-Contributors-CC-BY 4.0). 
Similar to other places in the Weinviertel, like the cellar lane in Raschala, in Wolfpassing we also find walls of press houses built with earth lumps, here locally known as Lehmwuzel (see Figure 9a). For ventilation, the relatively small window openings were not closed. A simple window frame on all four sides frames the wall opening. The lintel covering the narrow width of the window was made with a thin wooden board (see Figure 9b).
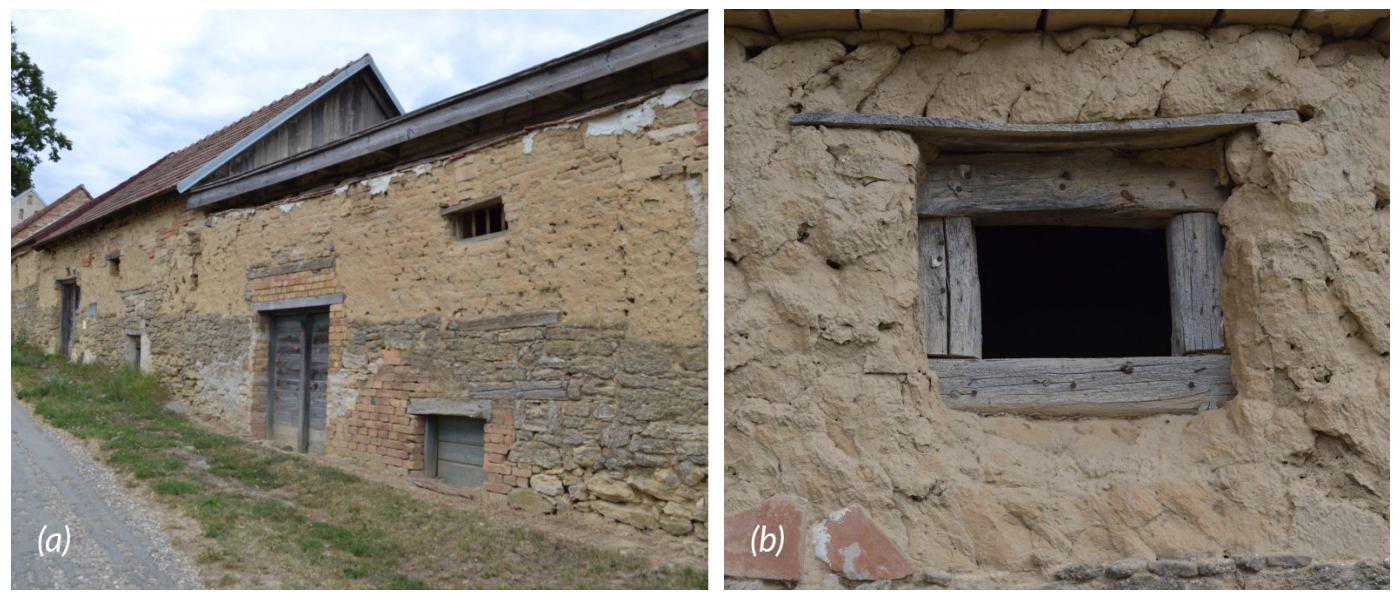

Figure 9. Building example from the cellar lane in Raschala, Wolfpassing: (a) wall made with mixed materials includingLehmwuzel and (b) window frame in a Lehmwuzel wall (Image Source: () Lehmbau im Weinviertel-ContributorsCC-BY 4.0).

Furthermore, outside the Weinviertel region, we find similar techniques, documented in the earth building cadastre, for example, in Heiligenbrunn in the south of Burgenland, which is the southeastern region of Austria. This dilapidated press house gives an insight into the irregular laying technique of Lehmwuzel (see Figure 10). In contrast to the construction method of walls with Lehmwuzel in the Weinviertel, in southern Burgenland these were often placed inside a wooden shuttering. For that reason this earth construction technique used in Burgenland is referred to as cob wall or gesatzte Mauer.

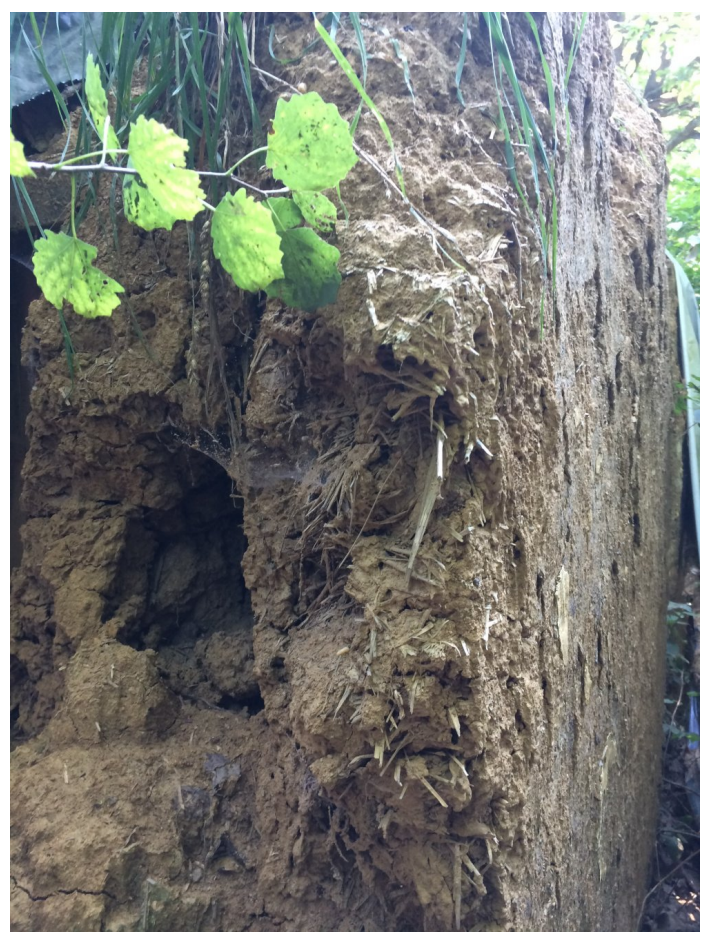

Figure 10. Detail of a cob wall in Heiligenbrunn, southern Burgenland (Image Source: (C) Lehmbau im Weinviertel-Contributors-CC-BY 4.0). 
We also encounter the technique of bricking up a wooden frame construction in the Weinviertel. Here, the primary construction made of wood, as we often find it in barns, is filled in with various local earth building techniques (see Figure 11a). The example from Frättingsdorf shows how the slanting wooden components were walled with adobe bricks. As a last step, the entire wall together with the wooden components was covered with whitewash (see Figure 11b).
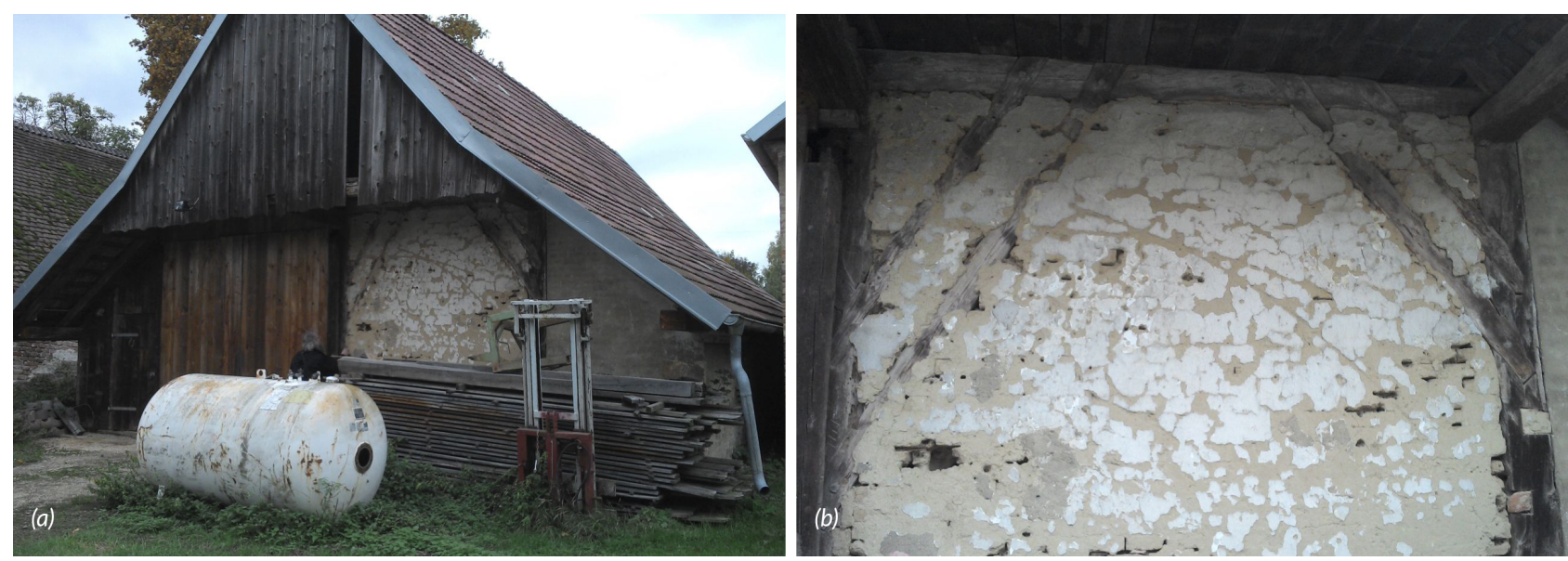

Figure 11. Building example from Frättingsdorf: (a) exterior facade and shape of the building and (b) wooden frame filled with earth and whitewash surface (Image Source: (C) Lehmbau im Weinviertel-Contributors-CC-BY 4.0).

In addition to the construction techniques of single objects, the earth building cadastre provides information about earth building methods and how these shape the image of entire streets in villages. In Gösing, for example, the connection between the topography of the terrain and the settlement of earth buildings becomes visible in the earth building cadastre when observing the whole settlement layout (see Figure 12).

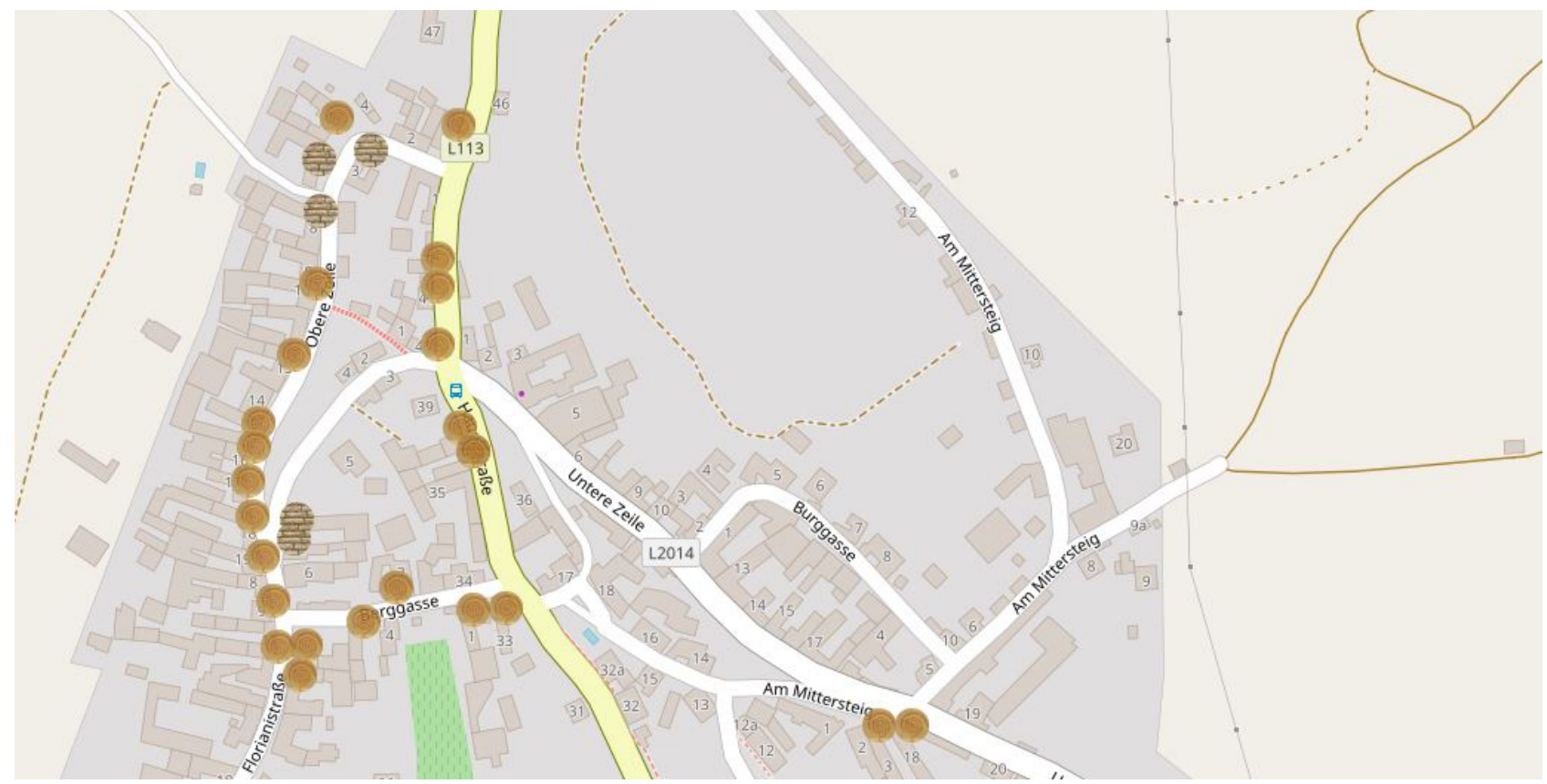

Figure 12. Map of Gösing with marked earth buildings from the cadastre (Map Source: Open Street Map, (C) OpenStreetMap-Contributors). 
Here, the topographical elevations were overbuilt with adobe buildings and this settlement layout indicates the use of clay for most of the settlement's buildings in a specific historic construction period.

\section{Conclusions}

Clay has shaped life in the Weinviertel for a long period, and its influence on farming practices in this rural landscape is significant and still visible. Different forms of application and building techniques have led to a unique vernacular architecture that is gradually disappearing due to various social developments. The Weinviertel is outstanding as one of Europe's regions containing a great diversity of different historic earth building techniques [1]. In particular, the presumably oldest techniques are only preserved by a few earth buildings as witnesses of a bygone vernacular building culture and their number decreases every day. Specific local and historical knowledge is needed to expand the scientific knowledge base and a Citizen Science approach can support the integration of these dispersed knowledge patterns into research projects. Furthermore, raising awareness among a wider public is key to a common understanding and protection of earth architecture as a traditional local heritage.

Clay is often regarded as a negligible historical fragment of earlier activities and constructions, although its importance as an emerging high-efficiency construction technology combining several natural resources is often disregarded. Bridging the gap between new technologies and local knowledge of historical applications helps to develop improved strategies for building renovation and integrates long-term empirical knowledge into the development of sustainable building products that meet today's needs and requirements.

Nevertheless, this methodological approach requires comprehensive strategies for knowledge transfer in both directions and offers for different target groups (e.g., schools, stakeholders, developers, researchers, etc.) to avoid frustration, uncertainty, and poor data quality. Adequate training and supporting materials covering the needs of the target groups to be reached are crucial for high data quality and measurable learning outcomes. It is important to educate people recognizing the numerous advantages of sustainable building materials-Citizen Science is a promising concept for this purpose.

With our Citizen Science approach, we have demonstrated that historic examples and artifacts can be collected, presented, and analyzed using web mapping and mobile applications as new innovative technologies to integrate a broader public. The study's findings indicate that the developed framework can easily be transferred to other slowly disappearing rural cultural assets to create comprehensive documentation and databases and raise awareness of the importance of these unique elements at different institutional levels (e.g., municipalities, schools, museums, and associations). Especially young people can be addressed with this approach using modern technologies and materials for interactive education.

An added value of the approach used is that the web application and database, as well as the supporting material for citizen scientist education can be used by teachers to motivate pupils to learn more about the region they live in and thus promote a regional identityschool subjects that can be linked to this topic would be history or geography. Furthermore, museums or tourism providers can use the supporting materials and the examples of the Lehmbaukataster to organize exhibitions, workshops, or guided tours in the region, which can also promote economic aspects and regional value creation.

Another strength of this Citizen Science approach is that the platform can be operated and evaluated beyond project durations with minimal effort. Both data collection and access to the data can thus also be made possible in the long term. In summary, these are all aspects for raising awareness of the importance of cultural heritage in one's region and subsequently for the enhancement and protection of cultural heritage. 


\section{Discussion}

Our study has demonstrated that local historical knowledge of earth architecture can be made accessible through a Citizen Science approach. In particular, technological advances and mobile devices promote both the involvement of interested laypersons and the preparation of data for knowledge transfer and awareness-raising. With appropriate support in the form of information materials and mapping guides, high data quality can be ensured, as other studies have shown. Of particular importance is the embedding of such a project in an existing institutional infrastructure, as many Citizen Science projects can only reach their full potential through a long-term establishment. However, this is hardly feasible in the current scientific funding systems and structures. A connection to educational institutions, university teaching, or associations and relevant organizations is therefore strongly recommended.

A not insignificant task of the presented project is the communication and translation of scientific knowledge into an understandable language as well as regular media work to draw attention to the project. This aspiration demands skills that are not self-evident in scientific biographies and should therefore be increasingly promoted. In our view, there is a need for further research in the field of communication and translation of scientific knowledge for a broader understanding.

The success of Citizen Science projects is highly dependent on the actors involved, as they can act either as door openers and multipliers or as door guards. Here, we see a research demand for a better understanding of the role of these actors and further development of appropriate methodological frameworks.

Author Contributions: Conceptualization and lead author, T.S.; Contributions to introduction and methodology, results, and conclusions, R.E., K.R., and H.F.; Contributions to introduction and methodology, H.F., F.O., and R.M.; writing-review and editing, H.F., F.O., and R.M.; project administration, T.S. and R.E.; funding acquisition, T.S. and R.E. All authors have read and agreed to the published version of the manuscript.

Funding: The project Lehmbau im Weinviertel was conducted within the Top Citizen Science initiative and the project Think Spatial! was conducted within the Sparkling Science research programmewww.sparklingscience.at. Both projects were funded by the Austrian Federal Ministry of Education, Science and Research.

Institutional Review Board Statement: Not applicable.

Informed Consent Statement: Informed consent was obtained from all subjects involved in the study.

Data Availability Statement: All data from the Citizen Science platform Lehmbau im Weinviertel can be accessed via cs-lehmbau.boku.ac.at. The data can be used freely and free of charge for both private and commercial purposes in accordance with the Creative Commons-Attribution license (CC-BY 4.0).

Acknowledgments: The authors want to mention the supportive activities of the participating schools: HAK/HAS Laa an der Thaya (Teacher: Mag. Marion Hansal-Pangratz) and HTL Donaustadt (Teacher: DI Erik Sacher). Furthermore, we want to thank the Museumsdorf Niedersulz for their support in organizing the kick-off meeting.

Conflicts of Interest: The authors declare no conflict of interest.

\section{References}

1. Dipasquale, L.; Correia, M.; Mecca, S. (Eds.) Terra Europae: Earthen Architecture in the European Union; Progetti Saperi Sentieri; ETS: Pisa, Italy 2011.

2. Meingast, R. Moderner Lehmbau—Lehm in Hocheffizienten Baukonzepten; Technical Report 80; Geologische Bundesanstalt, Haindorf bei: Langenlois, Austria, 2009.

3. Kunze, C.; Kubista, M.; Macho, K. Industrial Unfired Loam Brick Buildings with Passive House Standard; Proceedings CESB 07; Faculty of Civil Engineering, Czech Technical University: Prague, Czech Republic, 2007; pp. 735-740.

4. Feiglstorfer, H.; Meingast, R.; Ottner, F. Lehmbau: Der Einfluss von Lehm auf die vormoderne Baukultur in Ostösterreich. In MEMO Medieval and Early Modern Material Culture Online; MEMO: Salzburg, Austria, 2020. 
5. Feiglstorfer, H. Revealing traditions in earthen architecture. Analysis of earthen building material and traditional constructions in the Western Himalayas. In Art and Architecture in Ladakh: Cross-Cultural Transmissions in the Himalayas and Karakoram; Bue, E.L., Bray, D.J., Eds.; Brill: Leiden, The Netherlands; Boston, MA, USA, 2014; pp. 364-388.

6. Feiglstorfer, H. (Ed.) Earth Construction \& Tradition. Vol 1; IVA-Verlag: Vienna, Austria, 2016.

7. Feiglstorfer, H. (Ed.) Earth Construction E Tradition. Vol 2; IVA-ICRA Institute for Comparative Research in Architecture: Vienna, Austria, 2018.

8. Feiglstorfer, H.; Meingast, R.; Ottner, F. Lehm und Lehmbau in Weinviertler Kellergassen. Bestand, Erhaltung und Sanierung. Oesterreichische Z. Fuer Kunst Denkmalpfl. 2019, 73, 153-165.

9. Feiglstorfer, H. Mineral Building Traditions in the Himalayas: The Mineralogical Impact on the Use of Clay As Building Material; De Gruyter: Berlin, Germany; Boston, MA, USA, 2019.

10. Novotný, M. Hliněné Stavitelství na Moravě; Národní ústav lidové kultury: Strážnice, Czech Republic, 2014.

11. Škabrada, J.; Syrová-Anýžová, Z. Nejstarši Venkovské Domy ve Východních Čechách; Univerzita Pardubice: Pardubice, Czech Republic, 2018.

12. Žabičková, I.; Růžička, J. Earth construction in the Czech Republic. In Earth Construction \& Tradition. Vol 2; Feiglstorfer, H., Ed.; IVA-ICRA Institute for Comparative Research in Architecture: Vienna, Austria, 2018; pp. 105-121.

13. Ziegert, C. Lehmwellerbau: Konstruktion, Schäden und Sanierung; Number 37 in Berichte aus dem Konstruktiven Ingenieurbau; Fraunhofer IRB Verlag: Stuttgart, Germany, 2003.

14. Meingast, R. Nachweis historischer Lehmbautechniken in Ostösterreich. In Lehmbau Tradition und Moderne, Tagungsband; Niedersulz, M., Ed.; Museumsdorf Niedersulz: Atzenbrugg, Austria, 2014; pp. 21-27.

15. Feiglstorfer, H.; Meingast, R. Historischer Baubestand und Klimaschutz. Denkmalpfl. NiederöSterreich 2019, 61, 16-20.

16. Eßer, G. Kulturlandschaft der Kellergassen: Erforschung—Schutz—Erhaltung; Berger \& Söhne, Ferdinand: Horn, Austria, 2020.

17. Irwin, A. Citizen Science: A Study of People, Expertise and Sustainable Development; Routledge: London, UK, 1995.

18. Schauppenlehner, T. Lehmbau im Weinviertel: Mit Citizen Science eine gemeinsame Wissensbasis über Lehmbau schaffen. Oesterreichische Z. Fuer Kunst Denkmalpfl. 2019, 73, 105-107.

19. Ottner, F. Was Ist Lehm-Lehm \& Co. In Geologische Bundesanstalt: Haindorf bei Langenlois; Berichte Geol, B.-A., Ed.; Geologische Bundesanstalt: Vienna, Austria, 2009; Volume 80, pp. 5-10.

20. Ramml, F.C. Ziegelöfen und Lehmabbaue der Politischen Bezirke Mistelbach und Gänserndorf (Niederösterreich): Geschichte und Geologie; Number 27 in Archiv für Lagerstättenforschung/Geologische Bundesanstalt, Geolog; Bundesanst: Wien, Austria, 2014.

21. Wimmer-Frey, I.; Letouze-Zezula, G.; Müller, H.; Schwaighofer, B. Tonlagerstätten und Tonvorkommen Österreichs; Fachverb. d. Stein- u. Keramischen Industrie \& Verb. d. Österr; Ziegelwerke: Vienna, Austria, 1992.

22. Ottner, F.; Wriessnig, K.; Terhorst, B. Loess and paleosols from Aschet, Austria. Clay minerals as indicators of weathering intensity. In Proceedings of the 4th Mid-European Clay Conference 2008, Zakopane, Poland, 22-27 September 2008; Volume 33, pp. 122-123.

23. Bundesdenkmalamt (Ed.) Standards der Baudenkmalpflege, 2nd ed.; Bundesdenkmalamt: Wien, Austria, 2015.

24. Ecker, U. Historischer Lehmbau im Weinviertel. Rekonstruktion, Materialverwendung und Datierung mit Hilfe der Dendrochronologie. Master's Thesis, Institut für Angewandte Geologie, Universität für Bodenkultur, Vienna, Austria, 2017.

25. Feiglstorfer, H. Lehmbaubestand in Kellergassen. In Kulturlandschaft der Kellergassen; Eßer, G., Ed.; Verlag Berger: Horn, Vienna, Austria, 2020; pp. 107-113.

26. Knöbl, E. Historischer Lehmbau im Weinviertel. Objektkartierung und mineralogische Untersuchungen im Südwestlichen Weinviertel. Master's Thesis, Institut für Angewandte Geologie, Universität für Bodenkultur, Vienna, Austria, 2020.

27. Lerch, S. Lehmbau in ländlichen Siedlungsstrukturen des Weinviertel. Dokumentation und Analyse eines Lehmhauses in Großriedenthal. Bachelor's Thesis, Institut für Angewandte Geologie, Universität für Bodenkultur, Vienna, Austria, 2018.

28. Cohn, J.P. Citizen Science: Can Volunteers Do Real Research? BioScience 2008, 58, 192-197. [CrossRef]

29. Silvertown, J. A new dawn for citizen science. Trends Ecol. Evol. 2009, 24, 467-471. [CrossRef] [PubMed]

30. Shuttleworth, S.; Frampton, S. Constructing Scientific Communities: Citizen Science. Lancet 2015, 385, 2568. [CrossRef]

31. Grünzweil, B. Richtlinien für die Erstellung von Applikationen für Kinder im Vorschulalter. Master's Thesis, FH Hagenberg, Hagenberg, Austria, 2008.

32. Shamoo, A.E.; Resnik, D.B. Responsible Conduct of Research; Oxford University Press: Oxford, UK 2015.

33. Resnik, D.B.; Elliott, K.C.; Miller, A.K. A framework for addressing ethical issues in citizen science. Environ. Sci. Policy 2015, 54, 475-481. [CrossRef]

34. Phillips, T.; Ferguson, M.; Minarchek, M.; Porticella, N.; Bonney, R. User's Guide for Evaluating Learning Outcomes from Citizen Science; Technical Report; Cornell Lab of Ornithology: Ithaca, NY, USA, 2014.

35. Schauppenlehner, T.; Eder, R.; Gabriel, S.; Muhar, A.; Salak, B. Daten Teilen und die Privatsphäre Schützen: Der Gordische Knoten in Citizen Science Projekten? In Citizen Science-Quo Vadis! Zweite Österreichische Citizen Science Konferenz 2016; Heigl, F., Dörler, D., Weigelhofer, G., Eds.; Universität für Bodenkultur: Wien, Austria, 2016; pp. 1-2.

36. Heiderich, M.; Nava, E.A.V.; Heyes, G.; Lindsay, D. PHP. In Web Application Obfuscation; Heiderich, M., Nava, E.A.V., Heyes, G., Lindsay, D., Eds.; Syngress: Boston, MA, USA, 2011; pp. 151-175.

37. Dunlap, I.H. Building block V: MySQL. In Open Source Database Driven Web Development; Dunlap, I.H., Ed.; Chandos Information Professional Series; Chandos Publishing: Oxford, UK, 2006; pp. 105-124. 
38. Schauppenlehner, T.; Eder, R.; Gabriel, S.; Salak, B.; Muhar, A. Enabling pupils to contribute to societal challenges and participatory processes. In International Journal of E-Planning Research 2016 Annual Conference Abstracts; Institute of Geography and Spatial Planning, University of Lisbon: Lisbon, Portugal, 2016; pp. 1-2.

39. Rauter, T.; Schößwendter, J. Lehmbau im Weinviertel. Aufnahme Von Lehmbauten/Lössvorkommen und Untersuchung der Gewonnenen Lehm- Bzw. Lössproben. Bachelor's Thesis, Institut für Angewandte Geologie, Universität für Bodenkultur, Vienna, Austria, 2015.

40. Kriechhammer, M. Lehmbau im Weinviertel. Aufnahme Von Lehmbauten/Untersuchung der Gewonnenen Lehmbauproben. Bachelor's Thesis, Institut für Angewandte Geologie, Universität für Bodenkultur, Vienna, Austria, 2016.

41. Suanjak, A.M. Aufnahme von Historischen Lehmbauten im Weinviertel. Welche Lehmarten und Lehmbautechniken Wurden im Weinviertel Eingesetzt? Bachelor's Thesis, Institut für Angewandte Geologie, Universität für Bodenkultur, Vienna, Austria, 2017.

42. Gappmaier, P.; Tengler, M. Lehmbau im Weinviertel. Aufnahme Von Lehmbauten und Laboranalyse der Gezogenen Lehmprobe. Bachelor's Thesis, Institut für Angewandte Geologie, Universität für Bodenkultur, Vienna, Austria, 2019. 